\title{
The Mirror of Ideas
}

MICHEL TOURNIER

Translated by Jonathan F. Krell

Michel Tournier's myriad reflections on pairs both lowly and exalted-from fork and spoon to being and nothingnessreveal why his works have generated international attention and acclaim.

$\$ 25$ cloth

\section{Fugitive Poses}

Native American Indian Scenes of Absence and Presence

GERALD VIZENOR

"Gerald Vizenor demonstrates once more how and why he is at the absolute forefront of American writers and critical thinkers. The essays offered here gather past, present, and future into brilliantly disturbing ways of understanding how we articulate our selves and our worlds as Native American, post-indians, indigenous peoples, human beings."-Louis Owens $\$ 35$ cloth

National Book Critics Circle Finalist \section{Art for Art's Sake and Literary Life} How Politics and Markets Helped Shape the Ideology and Culture of Aestheticism, I790-1990 GENE H. BELL-VILLADA

"Lucid and learned.... much more than an exercise in retrieval, although it is splendid on this account alone, Bell-Villada has also joined debates about the Latin American novel, deconstructionism, and post-modernism, offering what is always in short supply: a wide-angled, historical, and penetrating perspective."-Russell Jacoby $\$ 18.95$ paper $/ \$ 45$ cloth

\section{Selected Letters of Hamlin Garland}

EDITED BY KEITH NEWLIN AND JOSEPH B. MCCULLOUGH

Frank, opinionated, and wide-ranging, Hamlin Garland's letters provide a valuable and entertaining portrait of American cultural and intellectual life in the years between 1890 and 1940 . $\$ 55$ cloth

Also by Hamlin Garland

Main-Travelled Roads $\$ 12$ paper

University of Nebraska Press

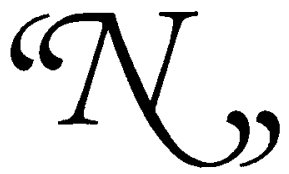

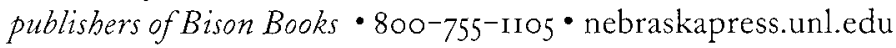

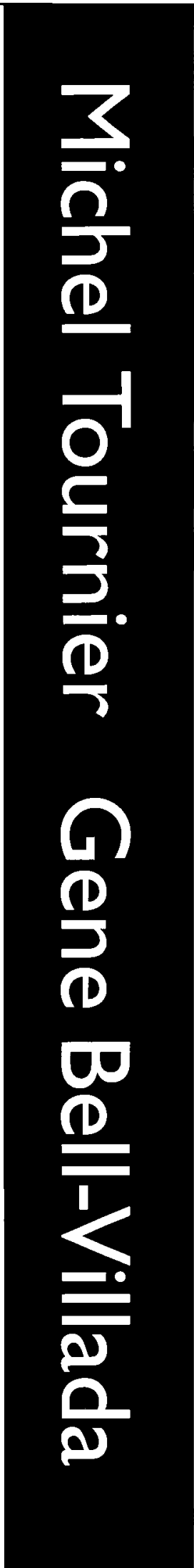




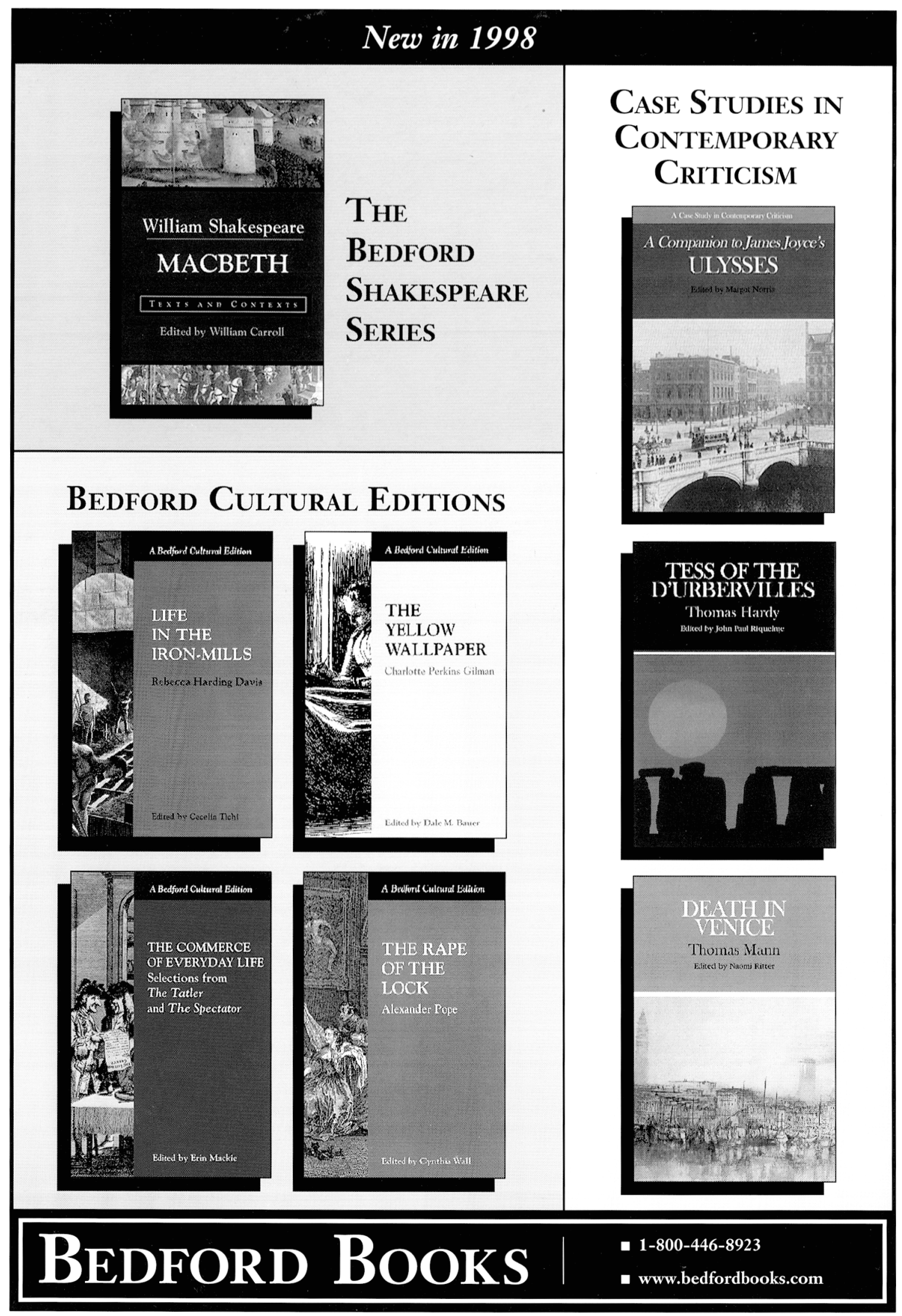

